\title{
The invasive sun coral Tubastraea coccinea hosting a native Christmas tree worm at Curaçao, Dutch Caribbean
}

\author{
Bert W. Hoeksema ${ }^{1,2}$ (1) $\cdot$ Harry A. ten Hove ${ }^{1}$ \\ Received: 29 December 2015 / Revised: 2 March 2016 / Accepted: 7 March 2016 / Published online: 2 April 2016 \\ (C) The Author(s) 2016. This article is published with open access at Springerlink.com
}

\begin{abstract}
Interspecific relationships of invasive species hosting a native associated species are noteworthy, particularly if the invasive does not have a similar relationship in its native range. The azooxanthellate Indo-Pacific coral Tubastraea coccinea (Dendrophylliidae) has become a widespread invasive in the tropical western Atlantic, where it was probably introduced as a fouling organism in the 1930s. During recent coral reef surveys this invader has been observed as host for a native tube worm, Spirobranchus giganteus (Serpulidae), at Curaçao, where this association was most commonly found on a shipwreck. Although Spirobranchus species are known to live in association with various shallow-water corals in the Atlantic and the IndoPacific, none of them has been recorded as an associate of a dendrophylliid or of an azooxanthellate coral before. This new association may be possible because of the generalist host selection of $S$. giganteus, which could have been facilitated by the availability of shipwrecks and other man-made substrates.
\end{abstract}

Keywords Coral reefs $\cdot$ Host coral $\cdot$ Generalist associate . Host range $\cdot$ Man-made substrate $\cdot$ Serpulid worm

Communicated by J. D. Reimer

Bert W. Hoeksema

bert.hoeksema@naturalis.nl

1 Naturalis Biodiversity Center, P.O Box 9517, 2300 RA Leiden, The Netherlands

2 Institute of Biology Leiden, Leiden University, P.O. Box 9505, 2300 RA Leiden, The Netherlands

\section{Introduction}

Many reports on introduced species as novel hosts for native parasites concern terrestrial ecosystems (e.g., Prider et al. 2009; Li et al. 2012; Meijer et al. 2015; Van Nieukerken and Geertsema 2015) and freshwater habitats (e.g., Glodosky and Sandland 2014; Subchev 2014). Only a few reports deal with marine host species that are recognized as invasives, and usually their parasites are co-introduced (e.g., Blakeslee et al. 2011).

Some generalist parasites are geographically widespread and already present during the introduction of the host species. For example, the American slipper limpet Crepidula fornicata (Linnaeus, 1758) is an introduced host for the boring sponge Cliona celata Grant, 1826, and the digenean trematode Himasthla elongata (Mehlis, 1831) in the northeastern part of the Atlantic (Hoeksema 1983; Thieltges et al. 2009), whereas both parasites also occur in their host's native range (Blakeslee et al. 2011; Carroll et al. 2015). Another example concerns ctenophores of the species Mnemiopsis leidyi Agassiz, 1865, which can become infested by parasitic larvae of the actiniarian genus Edwardsiella in the ctenophore's original native range along the North American east coast and also in its new, introduced range in northwestern Europe (Reitzel et al. 2009; Selander et al. 2010). It is difficult to find records of a marine invasive species that only hosts a particular kind of associate in its introduced range but not in its home range.

The scleractinian sun coral Tubastraea coccinea (Lesson, 1829 ) is increasingly notorious as an invasive species along the coastlines of the Caribbean, the Gulf of Mexico, and the Southwest Atlantic (Fenner and Banks 2004; Silva et al. 2014; Carlos-Júnior et al. 2015). As a native of the tropical IndoPacific, its occurrence in the western Atlantic was first recorded from the Caribbean islands Curaçao and Puerto Rico, where it may have been introduced in the 1930s as a fouling organism on an oil platform or a ship hull (Cairns 2000; 
Fenner 2001). Boschma (1953) reported on some large Tubastraea corals (maximum diameter $10 \mathrm{~cm}$ ) collected in 1948-1950 from mangrove roots, limestone, dead coral, and a ship hull in shallow water $(1 \mathrm{~m}$ depth) at Curaçao and its neighbouring islands Bonaire and Aruba. He identified these common corals as T. tenuilamellosa (Milne Edwards \& Haime, 1848), a junior synonym of $T$. coccinea (Cairns 2001). Roos (1971) remarked on its increasing abundance at Curaçao and its habitat expansion from shaded to more sunexposed rocky substrates. T. coccinea can be considered locally harmful in its introduced range, since it has been reported to compete with the Brazilian endemic coral Mussismilia hispida (Verrill, 1901) (see Creed 2006) and to live as epibiont on the mussel Perna perna (Linnaeus, 1758), also in Brazil (Mantelatto and Creed 2015).

During a study of the host range of the Christmas tree worm Spirobranchus giganteus (Pallas, 1766) at Curaçao, southern Caribbean, the non-native T. coccinea was discovered to act as host among several other newly recorded host species. Since $T$. coccinea belongs to the scleractinian family Dendrophylliidae (Cairns 2001; Arrigoni et al. 2014), and dendrophylliid corals were unknown to host Spirobranchus worms, this newly discovered association is discussed from an evolutionary and ecological perspective.

\section{Material and methods}

Spirobranchus host coral surveys were performed in 2014, 2015, and 2016 during 37 dives of $\sim 60$ min each at ten localities along the leeward coast of Curaçao (Table 1). The maximum depth of most dives was $30 \mathrm{~m}$, except for one (site \# 3) down to $39 \mathrm{~m}$. Only stony host corals were targeted, i.e., those belonging to fire corals (Hydrozoa: Anthoathecata) and scleractinians (Anthozoa: Hexacorallia). Secondary hosts overgrowing stony corals, such as octocorals and sponges (Hoeksema et al. 2015, 2016), were not included in the surveys. Both zooxanthellate and azooxanthellate scleractinian corals were examined, although azooxanthellate corals had not previously been recorded as host for Spirobranchus (e.g., Hunte et al. 1990; Dai and Yang 1995; Montebon and Yap 2009). Host corals were identified with the help of a field guide by Humann and DeLoach (2013).

A historical collection of 125 Tubastraea coccinea coral specimens (colonies and colony fragments) from Aruba (an island neighbouring Curaçao) was examined to detect a possible early representation of a Tubastraea -Spirobranchus association. Their maximum diameter ranges from 3 to $12 \mathrm{~cm}$, with an average of $6.9 \pm 2.3$ (mean $\pm \mathrm{SD}$ ). The specimens are housed in the Cnidaria collection of Naturalis Biodiversity Center (catalogue nr. RMNH Coel. 3538). They were collected on 4 May 1955 from an iron beam of the wharf of Eagle Petroleum Company by Dr. P. Wagenaar Hummelinck. Most specimens have traces of iron rust on their base.

\section{Results}

During the field surveys at Curaçao, a total of 26 stony coral species were observed with associated Christmas tree worms (Table 2). The deepest record concerns a colony of Madracis pharensis (Heller, 1868) at $39 \mathrm{~m}$ depth (site 3 in Table 1). Nine of the 26 coral species represent new host records for Spirobranchus giganteus, whereas four previously recorded associations were not found in the present study (Table 2).

Two of the new host records concern the scleractinian family Dendrophylliidae, which previously was not known to be involved in Spirobranchus associations (Martin and Britayev 1998; Stella et al. 2011). These two dendrophylliid coral species, Rhizopsammia goesi (Lindström, 1877) and Tubastraea coccinea Lesson, 1829, are also the first known azooxanthellate scleractinians inhabited by Spirobranchus. $R$. goesi is uncommon in shallow water at Curaçao, where it was found in small clusters of orange corals at three of the ten survey sites (sites 4, 6 , and 8 in Table 1; Fig. 1), while it was not recorded in earlier surveys at Curaçao (Roos 1971; Bak 1975; Van den Hoek et al.

Table 1 Localities at the leeward side of Curaçao where Spirobranchus host surveys were performed in 2014, 2015, and 2016

\begin{tabular}{lll}
\hline Locality name & Coordinates & Number of dives \\
\hline 1. Playa Kalki & $\mathrm{N} 12^{\circ} 22^{\prime} 29^{\prime \prime}, \mathrm{W} 069^{\circ} 09^{\prime} 29^{\prime \prime}$ & 4 \\
2. Playa Hundu & $\mathrm{N} 12^{\circ} 15^{\prime} 36^{\prime \prime}, \mathrm{W} 069^{\circ} 07^{\prime} 13^{\prime \prime}$ & 1 \\
3. St. Michielsbaai & $\mathrm{N} 12^{\circ} 08^{\prime} 54^{\prime \prime}, \mathrm{W} 068^{\circ} 59^{\prime} 58^{\prime \prime}$ & 2 \\
4. Slangenbaai & $\mathrm{N} 12^{\circ} 08^{\prime} 21^{\prime \prime}, \mathrm{W} 068^{\circ} 59^{\prime} 49^{\prime \prime}$ & 1 \\
5. Blauwbaai & $\mathrm{N} 12^{\circ} 08^{\prime} 06^{\prime \prime}, \mathrm{W} 068^{\circ} 59^{\prime} 12^{\prime \prime}$ & 5 \\
6. Piscadera Bay (CARMABI) & $\mathrm{N} 12^{\circ} 07^{\prime} 20^{\prime \prime}, \mathrm{W} 068^{\circ} 58^{\prime} 09^{\prime \prime}$ & 9 \\
7. Waterfactory & $\mathrm{N} 12^{\circ} 06^{\prime} 34^{\prime \prime}, \mathrm{W} 068^{\circ} 57^{\prime} 16^{\prime \prime}$ & 6 \\
8. Megapier (with ship wreck) & $\mathrm{N} 12^{\circ} 06^{\prime} 21^{\prime \prime}, \mathrm{W} 068^{\circ} 56^{\prime} 33^{\prime \prime}$ & 2 \\
9. Sea Aquarium & $\mathrm{N} 12^{\circ} 04^{\prime} 59^{\prime \prime}, \mathrm{W} 068^{\circ} 53^{\prime} 48^{\prime \prime}$ & 5 \\
10. Director's Bay & $\mathrm{N} 12^{\circ} 03^{\prime} 59^{\prime \prime}, \mathrm{W} 068^{\circ} 51^{\prime} 38^{\prime \prime}$ & 2 \\
\hline
\end{tabular}


Table 2 Coral species recorded in association with Spirobranchus giganteus worms at Curaçao

\begin{tabular}{lll}
\hline Species & Locality & Previous record \\
\hline
\end{tabular}

Class Hydrozoa, Order Anthoathecata, Suborder Capitata

Milleporidae

Millepora alcicornis Linnaeus, 1758

$1,3,5,6,7,8,9$

a, h

Millepora complanata Lamarck, 1816

$1,3,4,5,6,8,9$

f, g, h

Class Anthozoa, Subclass Hexacorallia, Order Scleractinia

Acroporidae

Acropora palmata (Lamarck, 1816)

$5 *, 7 *$

e

Agariciidae

Agaricia agaricites (Linnaeus, 1758)

Agaricia humilis (Verrill, 1901)

Agaricia lamarcki Milne Edwards and Haime, 1851

Astrocoeniidae

Stephanocoenia intersepta (Lamarck, 1816)

Dendrophylliidae

Rhizopsammia goesi (Lindström, 1877)

Tubastraea coccinea Lesson, 1829

Meandrinidae

Dendrogyra cylindrus Ehrenberg, 1834

Dichocoenia stokesii Milne Edwards and Haime, 1848

Eusmilia fastigiata (Pallas, 1766)

Meandrina meandrites (Linnaeus, 1758)

Merulinidae

Orbicella annularis (Ellis and Solander, 1786)

Orbicella faveolata (Ellis and Solander, 1786)

Orbicella franksi (Gregory, 1895)

Montastraeidae

Montastraea cavernosa (Linnaeus, 1767)

Mussidae

Colpophyllia natans (Houttuyn, 1772)

Diploria labyrinthiformis (Linnaeus, 1758)

Pseudodiploria strigosa (Dana, 1846)

$1,3,4,6,7,9,10$

$\mathrm{g}, \mathrm{h}$

$3,6,9,10$

10

$+$

$+$

6,7

$+$

8

$5,6,8,10$

$+$

$+$

7,9

$3,6,7,9$

3,7

6

$\begin{array}{ll}1,3,4,5,6,7,9 & \text { d, e, f, g, h } \\ 3,4,5,6,9 & + \\ 4,5,6,7,9 & + \\ 3,7,9,10 & \text { d, f, g, h } \\ 5,6,7,8,9 & \text { d } \\ 3,5,6 & \text { a, g } \\ 1,3,4,5,6,7,9,10 & \text { b, d, e, f, h }\end{array}$

Oculinidae

Oculina valenciennesi Milne Edwards and Haime, 1850

$\mathrm{b}^{* *}$

Pocilloporidae

Madracis auretenra Locke, Weil and Coates, 2007

Madracis decactis (Lyman, 1859)

Madracis formosa Wells, 1973

Madracis pharensis (Heller, 1868)

Poritidae

Porites astreoides Lamarck, 1816

Porites branneri Rathbun, 1887

Porites furcata Lamarck, 1816

Porites porites (Pallas, 1766)

$3,4,5,6,7,9$

$3,5,6$

$\mathrm{d}^{* * *}, \mathrm{e}^{* * *}$

e

e

3

c

$1,2,3,4,5,6,7,9,10$

d, e, f, g, h

e

e

$3,5,6,9$

d, e, f

Siderastreidae

Siderastrea siderea (Ellis and Solander, 1768)
$3,5,6,7,9,10$

$\mathrm{d}^{* * * *}, \mathrm{e}, \mathrm{f}, \mathrm{g}, \mathrm{h}$

Locality numbers refer to sites mentioned in Table 1 . New host records are marked by + . Previous host records are from Curaçao by (a) Pallas (1766), (b) Ten Hove (1970), (c) Steward-Van Es (1978), (d) Reuvekamp (1989); from Jamaica by (e) Scott (1987); from Barbados by (f) Hunte et al. (1990); from Cozumel, Mexico by (g) Petitjean and Myers (2005); from Bonaire by (h) Nygaard (2008). * association with Spirobranchus polycerus (Schmarda, 1861); ** species identification added by Roos (1971); *** recorded as Madracis mirabilis (Duchassaing and Michelotti, 1860); **** recorded as Siderastrea radians (Pallas, 1766) 


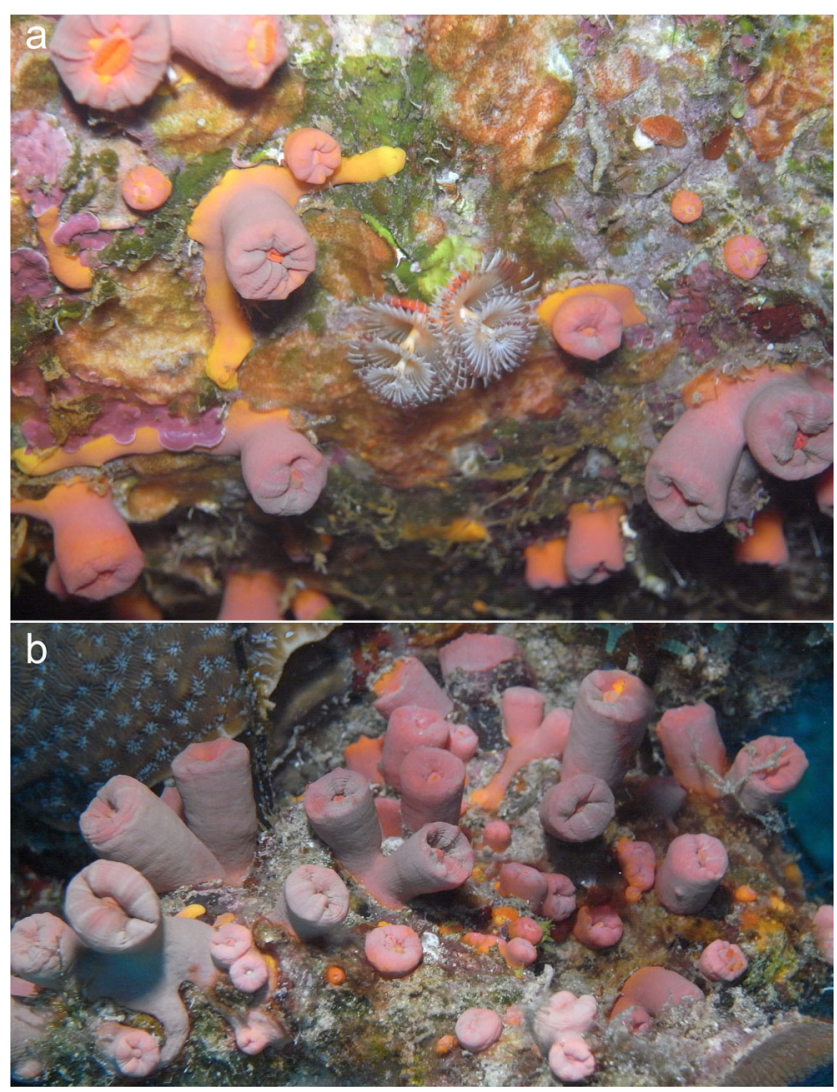

Fig. 1 Rhizopsammia goesi corals at two sites on Curaçao. a With a Spirobranchus giganteus worm on the hull of the shipwreck "Superior Producer" next to the Mega Pier, ca. $23 \mathrm{~m}$ depth. b Without Spirobranchus underneath an overhang at CARMABI, Piscadera Bay, ca. $15 \mathrm{~m}$ depth

1978). At only one of these three localities, Rhizopsammia was found in association with Spirobranchus, on the hull of a ship wreck where a single serpulid worm was found surrounded by several coral polyps (Table 2; Fig. 1a).

At four survey sites, corals of the invasive Tubastraea coccinea were observed with associated Spirobranchus worms (Fig. 2). It was difficult to quantify this association (as proportion of corals with worms) because the Tubastraea corals formed dense aggregations in which many colonies appeared to be fused or growing on top of each other, and therefore could not be clearly distinguished as separate units. At three of these four sites (sites 5, 6, and 10 in Table 1) this association was found at 1-2 $\mathrm{m}$ depths.

None of the Tubastraea specimens collected in 1955 from Aruba had remnants of Spirobranchus tubes on them. Hence, there is no proof yet that Christmas tree worms were previously associated with $T$. coccinea since its introduction in the Caribbean. Several of the old coral specimens had empty tubes of the serpulids Vermiliopsis annulata (Schmarda, 1861) and Hydroides sp. attached to their base, where the corals were connected to their metal substrate.

\section{Discussion}

The association of the invasive Tubastraea coccinea with the native Spirobranchus giganteus is remarkable, because T. coccinea and other dendrophylliid coral species were unknown as hosts for Spirobranchus worms, which includes their Indo-Pacific home range. The association of native Rhizopsammia and Spirobranchus species is of interest from an evolutionary perspective, since corals of the dendrophylliid genera Rhizopsammia and Tubastraea show strong morphological resemblances (Figs. 1 and 2), whereas they are closely but not directly related from a phylogenetic point of view (Cairns 2001; Arrigoni et al. 2014). These two dendrophylliids also represent the first records of azooxanthellate corals hosting Spirobranchus. Corals of both host species do not appear to overgrow the worm tubes (Figs. 1 and 2), and therefore the latter seem to function more as epifauna than as endofauna, whereas Spirobranchus worms in many other scleractinians become predominantly covered by coral tissue, with the exception of the tube opening (Nishi and Nishihira 1996; Hoeksema and Ten Hove 2014). The striking occurrence of $S$. giganteus in its new host, as well as in many other coral species, indicates that this tube worm is a generalist in its host selection, and perhaps more so than its congeners in the Indo-Pacific, which have not yet been observed to inhabit dendrophylliids.

In addition to the invasive Tubastraea coccinea, eight native coral species also represent new host records for Spirobranchus in the present study (Table 2), whereas several other Atlantic coral species have not yet been reported as hosts, such as those belonging to seven out of ten genera of the scleractinian family Mussidae (Budd et al. 2012): Favia, Isophyllia, Manicina, Mussa, Mussismilia, Mycetophyllia, and Scolymia. The cause for this restricted representation of mussid corals among a total of 30 recorded Spirobranchus hosts (Table 2) is unclear, all the more so because a similar host selection is not shown by Atlantic gall crabs (Van der Meij 2014).

In general, some Indo-Pacific Spirobranchus worms also appear to be generalists (Dai and Yang 1995; Montebon and Yap 2009), and one species is even able to settle on non-coral hosts, such as giant clams (Van der Schoot et al. 2016). Because the present report contains nine new host records for just the Caribbean, surveys are needed in other coral reef areas in order to obtain a more complete overview of host corals for Spirobranchus. This would provide a better overview of phylogenetic relationships of coral species acting as Spirobranchus hosts, as shown for various associates of mushroom corals (Fungiidae) in the Indo-Pacific (Hoeksema et al. 2012; Van der Meij et al. 2015).

The absence of known Spirobranchus-Tubastraea associations in the Indo-Pacific does not imply that the latter have no associated fauna in their native range. Tubastraea species in the Indo-Pacific are commonly under attack from 

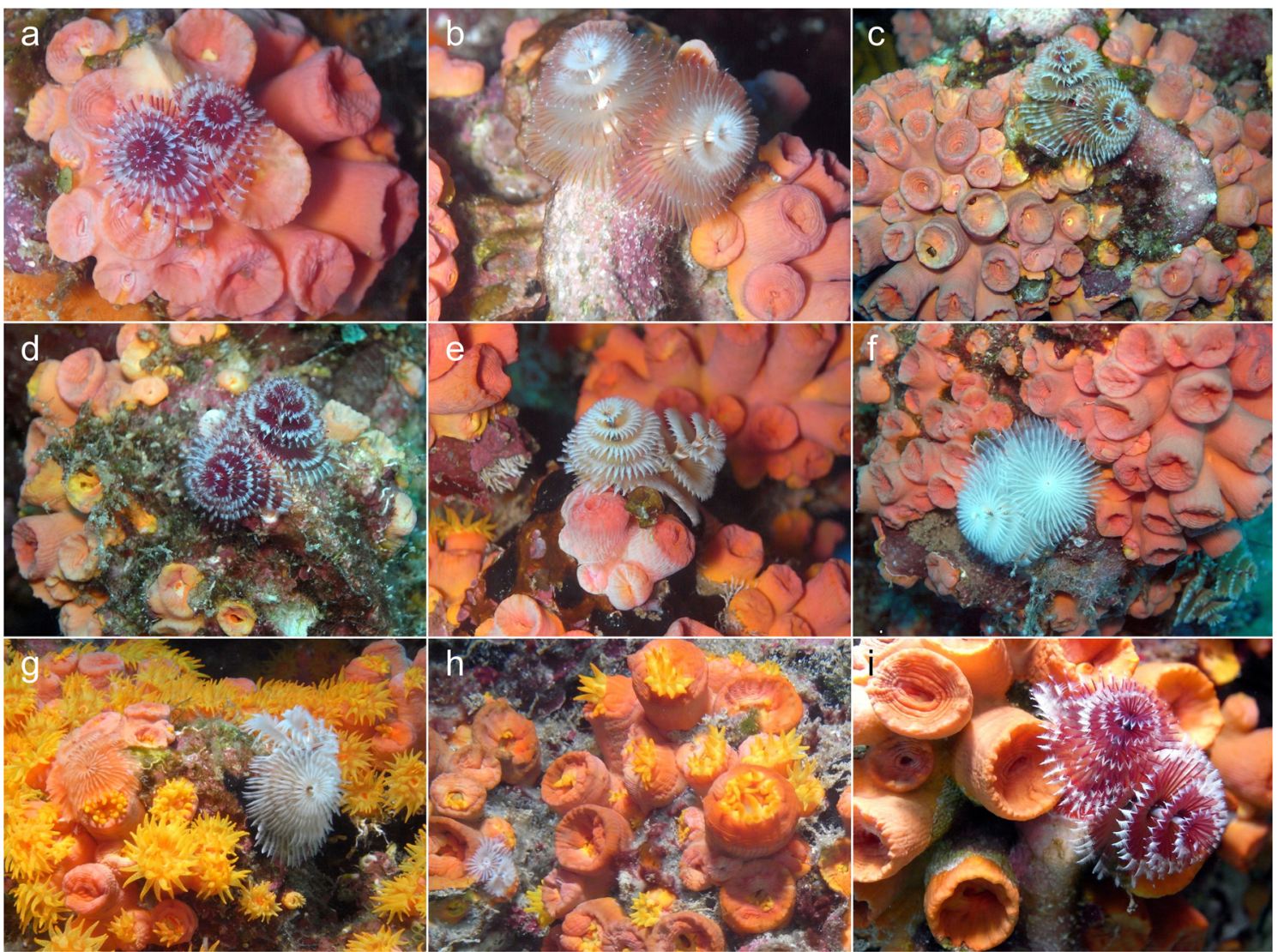

Fig. 2 Tubastraea coccinea corals with associated Spirobranchus giganteus at three sites on Curaçao. a-g On the superstructure and hull of the shipwreck "Superior Producer" next to the Mega Pier, 15-25 m depth. h Underneath an overhang at CARMABI, Piscadera Bay, ca. $1 \mathrm{~m}$ depth. i Underneath an overhang in Director's Bay, ca. 2 m depth

the Indo-Pacific (Ho et al. 2016). Since Tubastraea species in the western Atlantic were most likely introduced and dispersed as fouling organisms (Cairns 2000; Fenner 2001; Ferreira 2003; Fenner and Banks 2004), the availability of man-made substrate may be helpful in maintaining its population and also its association with $S$. giganteus.

Acknowledgments We thank staff of CARMABI and Curaçao Sea Aquarium for their hospitality and logistic support. We are also grateful to Antonio Baeza, Gerhard C. Cadée, Marco Faasse, Charles H.J.M. Fransen, Ton van Haaren, André Klicpera, Otto Moog, Godfried W.N.M. van Moorsel, Julian D. Reynolds, Menno Schilthuizen, and Erik J. van Nieukerken for discussions on introduced host species through ResearchGate. We thank two anonymous reviewers for their constructive comments. This publication is Ocean Heritage Foundation / Curaçao Sea Aquarium / Substation Curaçao $(\mathrm{OHF} / \mathrm{CSA} / \mathrm{SC})$ contribution number 23.

Open Access This article is distributed under the terms of the Creative Commons Attribution 4.0 International License (http:// creativecommons.org/licenses/by/4.0/), which permits unrestricted use, distribution, and reproduction in any medium, provided you give appropriate credit to the original author(s) and the source, provide a link to the Creative Commons license, and indicate if changes were made.

Shearer 2009; Moreira et al. 2014) but since recently also in 


\section{References}

Arrigoni R, Kitano YF, Stolarski J, Hoeksema BW, Fukami H, Stefani F, Galli P, Montano S, Castoldi E, Benzoni F (2014) A phylogeny reconstruction of the Dendrophylliidae (Cnidaria, Scleractinia) based on molecular and micromorphological criteria, and its ecological implications. Zool Scr 43:661-688. doi:10.1111/zsc. 12072

Bak RPM (1975) Ecological aspects of the distribution of reef corals in the Netherlands Antilles. Bijdr Dierkd 45:181-190

Blakeslee AM, Altman I, Miller AW, Byers JE, Hamer CE, Ruiz GM (2011) Parasites and invasions: a biogeographic examination of parasites and hosts in native and introduced ranges. J Biogeogr 39:609622. doi:10.1111/j.1365-2699.2011.02631.x

Boschma H (1953) On specimens of the coral genus Tubastraea, with notes on phenomena of fission. Stud Fauna Curaçao 4:109-119, pls. 9-12

Budd AF, Fukami H, Smith ND, Knowlton N (2012) Taxonomic classification of the reef coral family Mussidae (Cnidaria: Anthozoa: Scleractinia). Zool J Linnean Soc 166:465-529. doi:10.1111/j. 1096-3642.2012.00855.x

Cairns SD (2000) A revision of the shallow-water azooxanthellate Scleractinia of the Western Atlantic. Stud Nat Hist Caribb Reg 75: $1-240$

Cairns SD (2001) A generic revision and phylogenetic analysis of the Dendrophylliidae (Cnidaria: Scleractinia). Smithson Contrib Zool 615:1-75

Carlos-Júnior LA, Barbosa NPU, Moulton TP, Creed JC (2015) Ecological niche model used to examine the distribution of an invasive, non-indigenous coral. Mar Environ Res 103:115-124. doi:10. 1016/j.marenvres.2014.10.004

Carroll JM, O'Shaughnessy KA, Diedrich GA, Finelli CM (2015) Are oysters being bored to death? Influence of Cliona celata on Crassostrea virginica condition, growth and survival. Dis Aquat Org 117:31-44. doi:10.3354/dao02928

Creed JC (2006) Two invasive alien azooxanthellate corals, Tubastraea coccinea and Tubastraea tagusensis, dominate the native zooxanthellate Mussismilia hispida in Brazil. Coral Reefs 25:350. doi:10.1007/s00338-006-0105-x

Creed JC, de Paula AF (2007) Substratum preference during recruitment of two invasive alien corals onto shallow subtidal tropical rocky shores. Mar Ecol Prog Ser 330:101-111. doi:10.3354/ meps330101

Dai CF, Yang HP (1995) Distribution of Spirobranchus giganteus corniculatus (Hove) on the coral reefs of southern Taiwan. Zool Stud 34:117-125

Faucci A, Toonen RJ, Hadfield MG (2007) Host shift and speciation in a coral-feeding nudibranch. Proc R Soc B 274:111-119. doi:10.1098/ rspb.2006.3685

Fenner D (2001) Biogeography of three Caribbean corals (Scleractinia) and the invasion of Tubastraea coccinea into the Gulf of Mexico. Bull Mar Sci 69:1175-1189

Fenner D, Banks K (2004) Orange cup coral Tubastraea coccinea invades Florida and the Flower Garden Banks, Northwestern Gulf of Mexico. Coral Reefs 23:505-507. doi:10.1007/s00338-004-0422-x

Ferreira CEL (2003) Non-indigenous corals at marginal sites. Coral Reefs 22:498. doi:10.1007/s00338-003-0328-z

Gittenberger A, Gittenberger E (2005) A hitherto unnoticed adaptive radiation: epitoniid species (Gastropoda: Epitoniidae) associated with corals (Scleractinia). Contrib Zool 74:125-203

Gittenberger A, Hoeksema BW (2013) Habitat preferences of coralassociated wentletrap snails (Gastropoda: Epitoniidae). Contrib Zool 82:1-25

Glodosky CM, Sandland GJ (2014) Assessing host competency between native and invasive snail species exposed to the native parasite
Echinostoma revolutum. Aquat Invasions 9:87-93. doi:10.3391/ai. 2014.9.1.07

Harris LG (1975) Studies on the life history of two coral-eating nudibranchs of the genus Phestilla. Biol Bull 149:539-550

Ho MJ, Chia MH, Cen CA (2016) Wall of orange cup coral, Tubastraea coccinea, at the inlet breakwaters of a nuclear power plant, southern Taiwan. Mar Biodivers. doi:10.1007/s12526-016-0469-2

Hoeksema BW (1983) Excavation patterns and spiculae dimensions of the boring sponge Cliona celata from the SW Netherlands. Senckenberg Marit 15:55-85

Hoeksema BW, ten Hove HA (2014) First record of a christmas tree worm in a mushroom coral (Loyalty Islands, Southwest Pacific). Coral Reefs 33:717. doi:10.1007/s00338-014-1175-9

Hoeksema BW, van der Meij SET, Fransen CHJM (2012) The mushroom coral as a habitat. J Mar Biol Assoc UK 92:647-663. doi:10.1017/ S0025315411001445

Hoeksema BW, Lau YW, ten Hove HA (2015) Octocorals as secondary hosts for Christmas tree worms at Curaçao. Bull Mar Sci 91:489490. doi:10.5343/bms.2015.1049

Hoeksema BW, ten Hove HA, Berumen MI (2016) Christmas tree worms evade smothering by a coral-killing sponge in the Red Sea. Mar Biodivers 48:15-16. doi:10.1007/s12526-015-0339-3

Humann P, Deloach N (2013) Reef coral identification: Florida, Caribbean, Bahamas, 3rd edn. New World Publications, Jacksonville $(\mathrm{Fl})$

Hunte W, Conlin BE, Marsden JR (1990) Habitat selection in the tropical polychaete Spirobranchus giganteus. I. Distribution on corals. Mar Biol 104:87-92. doi:10.1007/BF01313161

Li J, Jin Z, Song W (2012) Do native parasitic plants cause more damage to exotic invasive hosts than native non-invasive hosts? An implication for biocontrol. PLoS ONE 7(4), e34577. doi:10.1371/journal. pone. 0034577

Mantelatto MC, Creed JC (2015) Non-indigenous sun corals invade mussel beds in Brazil. Mar Biodivers 45:605-606. doi:10.1007/s12526014-0282-8

Martin D, Britayev TA (1998) Symbiotic polychaetes: review of known species. Oceanogr Mar Biol Annu Rev 36:217-340

Meijer K, Zemel H, Chiba S, Smit C, Beukeboom LW, Schilthuizen M (2015) Phytophagous insects on native and non-native host plants: combining the community approach and the biogeographical approach. PLoS ONE 10(5), e0125607. doi:10.1371/journal.pone. 0125607

Montebon ARF, Yap HT (2009) Abundance, density, and size structure of Spirobranchus gaymardi (Polychaeta, Serpulidae) in Philippine coral reefs. Bull Mar Sci 84:93-108

Moreira PL, Ribeiro FV, Creed JC (2014) Control of invasive marine invertebrates: an experimental evaluation of the use of low salinity for managing pest corals (Tubastraea spp.). Biofouling 30:639-650. doi:10.1080/08927014.2014.906583

Nishi E, Nishihira M (1996) Age-estimation of the Christmas tree worm Spirobranchus giganteus (Polychaeta, Serpulidae) living buried in the coral skeleton from the coral-growth band of the host coral. Fish Sci 62:400-403

Nygaard L (2008) Size distribution of Spirobanchus giganteus in Bonaire: is there a benefit of recruitment to live coral? Physis 3: 25-30

Pallas PS (1766) Miscellanea zoologica quibus novae imprimis atque obscurae animalium species describuntur et observationibus iconibusque illustrantur. Van Cleef, Hague Comitum

Petitjean SE, Myers AE (2005) Age, characterization, and distribution of Spirobranchus giganteus on Paraiso Reef. Epistimi 8:1-4

Prider J, Watling J, Facelli JM (2009) Impacts of a native parasitic plant on an introduced and a native host species: implications for the control of an invasive weed. Ann Bot 103:107-115. doi:10.1093/ $\mathrm{aob} / \mathrm{men} 214$ 
Reitzel AM, Daly M, Sullivan JC, Finnerty JR (2009) Comparative anatomy and histology of developmental and parasitic stages in the life cycle of the lined sea anemone Edwardsiella lineata. J Parasitol 95: 100-112. doi:10.1645/GE-1623.1

Reuvekamp D (1989) Verspreiding en substraatgebruik van Spirobranchus op Curaçao. MSc Thesis, University of Amsterdam

Rodríguez-Villalobos JC, Ayala-Bocos A, Hernández L (2016) Predation by Epidendrium billeeanum on Tubastrea coccinea: use of the denuded skeleton for laying eggs. Coral Reefs 35:271. doi:10.1007/ s00338-015-1379-7

Roos PJ (1971) The shallow-water stony corals of the Netherlands Antilles. Stud Fauna Curaçao 37:1-108

Scott PJB (1987) Associations between corals and macro-infaunal invertebrates in Jamaica, with a list of Caribbean and Atlantic coral associates. Bull Mar Sci 40:271-286

Selander E, Møller LF, Sundberg P, Tiselius P (2010) Parasitic anemone infects the invasive ctenophore Mnemiopsis leidyi in the North East Atlantic. Biol Invasions 12:1003-1009. doi:10.1007/s10530-0099552-y

Shearer TL (2009) Population analysis of an introduced coral species, Tubastrea coccinea, in Florida. In: Pollock NW (ed) Diving for Science 2009. Proceedings of the American Academy of Underwater Sciences, 28th Scientific Symposium, Dauphin Island, Al. AAUS, Atlanta, GA, pp 229-236

Silva AG, de Paula AF, Fleury BG, Creed JC (2014) Eleven years of range expansion of two invasive corals (Tubastraea coccinea and T. tagusensis) through the southwest Atlantic (Brazil). Estuar Coast Shelf Sci 141:9-16. doi:10.1016/j.ecss.2014.01.013

Stella JS, Pratchett MS, Hutchings PA, Jones GP (2011) Coral-associated invertebrates: diversity, ecology importance and vulnerability to disturbance. Oceanogr Mar Biol Annu Rev 49:43-104. doi:10.1201/ b11009-3
Steward-Van Es YE (1978) De evertebratenfauna op levende koralen. MSc Thesis, University of Utrecht

Subchev M (2014) The genus Branchiobdella Odier, 1823 (Annelida, Clitellata, Branchiobdellida): a review of its European species. Acta Zool Bulg 66:5-20

Ten Hove HA (1970) Serpulinae (Polychaeta) from the Caribbean: I The genus Spirobranchus. Stud Fauna Curaçao 32:1-57

Thieltges DW, Reise K, Prinz K, Jensen KT (2009) Invaders interfere with native parasite-host interactions. Biol Invasions 11:14211429. doi:10.1007/s10530-008-9350-y

Van den Hoek C, Breeman AM, Bak RPM, Van Buurt G (1978) The distribution of algae, corals and gorgonians in relation to depth, light attenuation, water movement and grazing pressure in the fringing coral reef of Curacao, Netherlands Antilles. Aquat Bot 5:1-46. doi: 10.1016/0304-3770(78)90045-1

Van der Meij SET (2014) Host species, range extensions, and an observation of the mating system of Atlantic shallow-water gall crabs (Decapoda: Cryptochiridae). Bull Mar Sci 90:1001-1010. doi:10. 5343/bms.2014.1017

Van der Meij SET, Fransen CHJM, Pasman LR, Hoeksema BW (2015) Phylogenetic ecology of gall crabs (Cryptochiridae) as associates of mushroom corals (Fungiidae). Ecol Evol 5:5770-5780. doi:10. 1002/ece3.1808

Van der Schoot R, Scott CM, ten Hove HA, Hoeksema BW (2016) Christmas tree worms as epibionts of giant clams at Koh Tao, Gulf of Thailand. Mar Biodivers. doi:10.1007/s12526-015-0439-0

Van Nieukerken EJ, Geertsema H (2015) A new leafminer on grapevine and Rhoicissus (Vitaceae) in South Africa within an expanded generic concept of Holocacista (Insecta, Lepidoptera, Heliozelidae). ZooKeys 507:41-97. doi:10. 3897/zookeys.507.9536 